\title{
Marine snow derived from abandoned larvacean houses: sinking rates, particle content and mechanisms of aggregate formation
}

\author{
Jørgen L. S. Hansen ${ }^{1}$, Thomas Kiørboe ${ }^{2, *}$, Alice L. Alldredge ${ }^{3}$ \\ ${ }^{1}$ Marine Biological Laboratory, Strandpromenaden 5, DK-3000 Helsingor, Denmark \\ ${ }^{2}$ Danish Institute for Fisheries Research, Charlottenlund Castle, DK-2920 Charlottenlund, Denmark \\ ${ }^{3}$ University of California, Santa Barbara, Marine Sciences Institute, Dept of Biological Sciences, Santa Barbara, \\ California 93106, USA
}

\begin{abstract}
The dynamics and formation mechanisms of marine snow aggregates from abandoned larvacean houses were examined by laboratory experiments and field sampling during a spring diatom bloom in a shallow fjord on the west coast of the USA. Intact aggregates were sampled both from sediment traps and directly from the water column by divers. All aggregates were composed of 1 abandoned house of the larvacean Oikopleura dioica to which numerous diatoms, fecal pellets, ciliates, and amorphous detritus were attached. High vertical flux rates (20000 to 120000 houses $\mathrm{m}^{-2} \mathrm{~d}^{-1}$ ) and settling velocities (average $120 \mathrm{~m} \mathrm{~d}^{-1}$ ) imply a rapid turnover of suspended larvacean houses, and concentrations of diatoms and fecal pellets in the aggregates exceeding ambient concentrations by 3 to 5 orders of magnitude suggest their potential importance in driving the vertical flux of particles. Identical particle assemblages were observed in aggregates collected in the water column and in sediment traps. Most of the fecal pellets found in the houses were most likely produced by the larvaceans themselves. Numbers of diatoms per house corresponded with the diatom concentrations in the ambient water and, on average, each aggregate contained diatoms in abundances corresponding to those found in $4.5 \mathrm{ml}$ of ambient water. Laboratory measurements showed that larvacean houses scavenge diatoms and fecal pellets while sinking, and observed scavenging rates were similar to those predicted from theory. However, both predicted and observed scavenging rates un experiments were orders of magnitude too low to account for the particle content observed on aggregates from the water column. Based on models, shear coagulation was also assessed to be insignificant in forming aggregates. It is concluded that most of the particles become attached to the incurrent filters of the larvacean house while it is still inhabited, and that shear and sinking insignificantly contribute to particle collisions and adhesions on the abandoned house.
\end{abstract}

KEY WORDS: Marine snow · Larvaceans - Scavenging Mechanisms of aggregation

\section{INTRODUCTION}

Macroscopic marine aggregates, known collectively as marine snow, are ubiquitous in the sea (Alldredge \& Silver 1988), and sedimentation of organic matter to the sea floor occurs primarily in the form of aggregates (Fowler \& Knauer 1986). Marine snow may contain all kinds of particulate material also found suspended in

\footnotetext{
•Addressee for correspondence.E-mail: tk@dfu.min.dk
}

the water column, and the composition of aggregates ranges from pure phytoplankton to aggregates composed of amorphous detritus (Alldredge \& Silver 1988).

Members of the zooplankton community such as pteropods, larvaceans and salps produce gelatinous feeding nets and houses which, together with their fecal pellets, also occasionally comprise the aggregates (Alldredge 1972, Pomeroy \& Deibel 1980, Morris et al. 1988, Bathmann et al. 1991). Larvaceans, in particular, form a rich source of marine snow as they periodically abandon their old houses (Alldredge 1972, 1976, 
Davoll \& Silver 1986, Alldredge \& Silver 1988). These spherical or elliptical houses consist of an outer mucopolysaccharide wall and fine mucous nets (Alldredge 1977) which, in themselves, add a small amount of organic matenal to the aggregates. However, a varlety of particles from the surrounding sea water become attached to the houses. The aggregates contain phytoplankton cells. bacterı, flagellates, cillates, fecal pellets, mıneral grains and other partıcles in concentrations that exceed bulk water concentrations by orders of magnitude (Taguchi 1982, Davoll \& Silver 1986, Alldredge \& Silver 1988). Due to the accumulation of living organisms these houses may become sites of elevated microbial activity (Davoll \& Silver 1986), and their high particle content makes them suitable as food for the zooplankton (Alldredge 1972, Steinberg et al. 1994). On the other hand, sinking rates exceeding $100 \mathrm{~m} \mathrm{~d}^{-1}$ (Silver \& Alldredge 1981, Taguchı 1982, Gorsky et al. 1984) also suggest that larvacean houses increase the export of microorganisms out of the photic zone. However, the role of larvaceans in facilitating the sedimentation of organic carbon and micioorganısms is largely unknown.

The accumulation of particles on the house is believed to occur as the larvacean pumps water through the house and the larger partıcles are screened by the incurrent filters. which gradually clog (Alldredge 1977. Davoll \& Silver 1986). In addition to this 'biological' process of aggregation, physical mechanisms such as scavenging and shear coagulation may contribute to the particle enrichment of the house after it has been abandoned. For example, Morris et al. (1988) hypothesised that sinking mucous structures of salps collect significant amounts of particulate material in the water column by scavenging; and. based on theoretical considerations, Stoltzenbach (1993) concluded that scavenging of small particles by fast sinking porous aggregates plays an important role in the vertical particle transport in the ocean. However, the significance of particle scavenging by larvacean houses and other marine snow aggregates is poorly understood. Because larvacean houses are coherent structures of unuform shape they provide a unique simple model with which the significance of partıcle scavenging can be examuned.

This study examines the dynamics and formation mechanisms of manne snow aggregates from abandoned larvacean houses during a spring diatom bloom on the U.S west coast with a view to assessing their role in driving the vertical particle fluxes. We present data on house production rates. sinking velocities, aggregate flux rates, aggregate composition and laboratory measurements of scavenging rates, and we discuss the mechanisms of aggregate formation. We show that shear coagulation and scavenging are both insignificant processes, and that most particles become attached to the larvacean house due to the filtering activity of its inhabitant

\section{MATERIALS AND METHODS}

This field study was conducted trom Apnl 13 to 24, 1994, in East Sound, Orcas Island, Washington, at a station $\left(48^{\circ} 40^{\prime} 02^{\prime \prime} \mathrm{N}, 122^{\circ} 54^{\prime} 01^{\prime \prime} \mathrm{W}\right)$ with a bottom depth of $28 \mathrm{~m}$ (Fig. 1). A diatom bloom, dominated by Thalassiosira mendiolana, Chaetoceros spp. and Thalassionema nitschiordes, developed during the study period, with chlorophyll concentrations increasing to about $20 \mathrm{\mu g} \mathrm{l}^{-1}$ (Kıørboe et al. 1996).

Measurements of plankton abundance. Water samples were collected dally between 08:00 and 09:00 h in 301 Go-Flo bottles at the sub-surface fluorescence maximum (4 to $8 \mathrm{~m}$ ) and at $21 \mathrm{~m}$ depth (deployment depth of sediment traps). Between April 19 and 21 , additional water samples were collected at 18:00 h

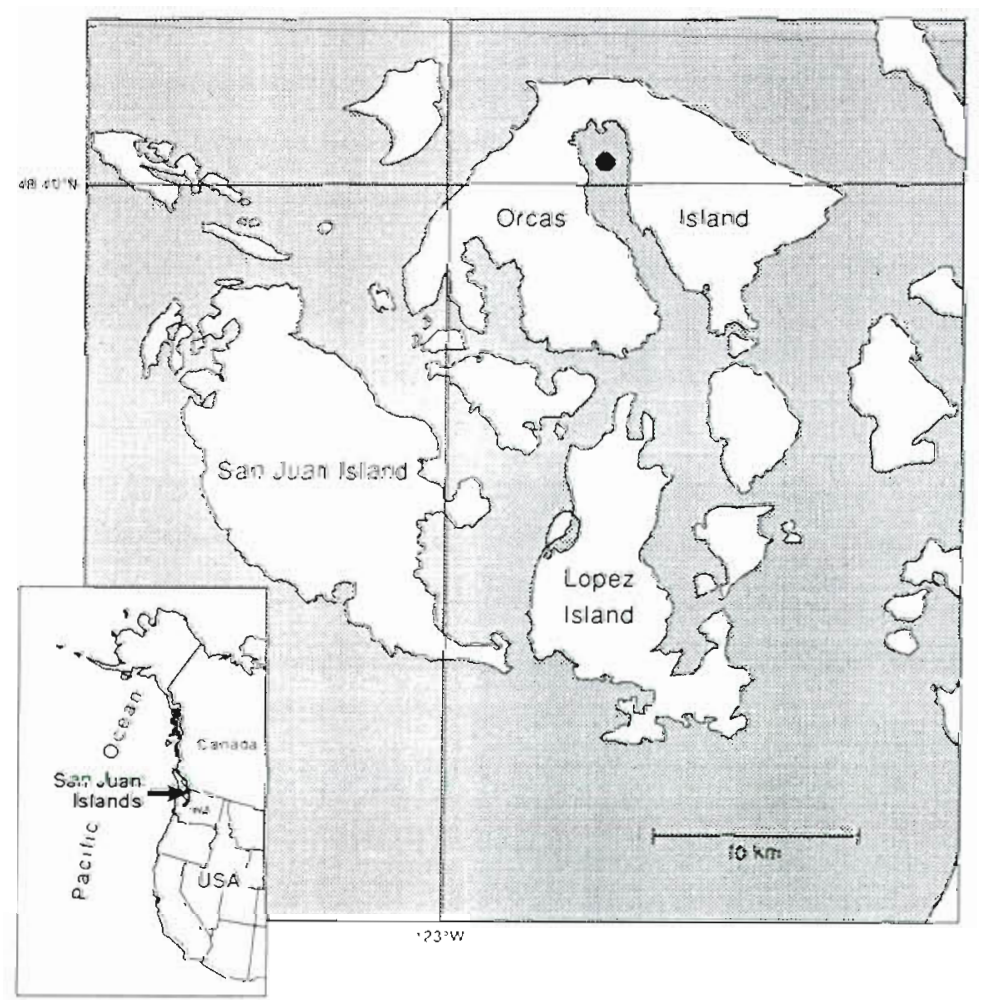

Flg 1 Study site in East Sound. Orcas Island, Washington $\left(48^{\circ} 40^{\circ} 02^{\prime \prime} \mathrm{N}\right.$. $122^{\circ} 54^{\prime} 01^{\prime \prime}(\mathrm{W})$ 
Copepod fecal pellets and phytoplankton were identified and counted as described by Kiørboe et al. (1996). Zooplankton were collected daily between 12:00 and 15:00 h with a $50 \mathrm{~cm}$ diameter, $333 \mu \mathrm{m}$ mesh size net hauled vertically from $20 \mathrm{~m}$ to the surface. From April 19 to 24 , zooplankton were also collected in $30 \mathrm{l}$ Go-Flo bottles at mean depths of $3,6,10,13,16$ and $20 \mathrm{~m}$. Bottles from the 3 shallowest and 3 deepest depths were drained through a $200 \mu \mathrm{m}$ mesh and pooled to yield mean abundances above and below $10 \mathrm{~m}$ respectively. On April 19 and 20 both types of collection were also repeated at $22: 00 \mathrm{~h}$. Larvaceans from all samples were quantified and their trunk lengths measured using microscopy. On April 21 and 23, divers measured the concentration and occupancy rate of visually identifiable larvacean houses passing through a $17.2 \mathrm{~cm}$ diameter wire hoop attached to a hand held General Oceanic model 2030 flow meter. Fifty houses were counted on each of 3 transects at 5, 10 and $20 \mathrm{~m}$ depths. Occupied houses were easily discernable due to the beating of the animal's tail.

Sampling of larvacean houses. From April 19 to 24, divers collected larvacean houses in syringes at 5, 10 and $20 \mathrm{~m}$ depths in batches of 10 to 100 houses per sample as described in Alldredge (1992). Sample volumes were measured, phytoplankton and fecal pellets were counted and numbers of fecal pellets and phytoplankton cells attached to the houses were calculated by subtracting ambient background concentrations measured at 5 and $21 \mathrm{~m}$ depth (Kiørboe et al. 1996). Additional larvacean houses were collected and kept unpreserved for 1 to $2 \mathrm{~d}$ for measurements of sinking velocity and scavenging efficiency (see below). On April 22, 20 live larvaceans of the species Oikopleura dioica were collected at the nearby Friday Harbor Laboratory pier and kept individually in $500 \mathrm{ml}$ beakers containing water from $5 \mathrm{~m}$ in East Sound at $12^{\circ} \mathrm{C}$. The number of houses they abandoned over two $12 \mathrm{~h}$ periods was monitored. Animals were transferred to fresh sea water at the end of the first period.

Sinking rates. Sinking velocities of larvacean houses collected by divers were measured in $100 \mathrm{ml}$ graduated cylinders filled with filtered seawater from East Sound; about 10 houses were released individually by pipette $2 \mathrm{~cm}$ below the surface and sinking times between 6 marks were noted. Only terminal velocities were used. Sinking velocity was also measured for houses being aged in the laboratory (see below)

Scavenging. The potential of settling larvacean houses to scavenge particles from the water column was examined experimentally: larvacean houses were collected in the field on April 19 and incubated in water from the station at the depth of fluorescence maximum (about $5 \mathrm{~m}$ ) on a rolling table $(12 \mathrm{rpm}, 2 \mathrm{l}$ bottles with $120 \mathrm{~mm}$ radius) or in a standing jar (con- trol). Houses were sampled at the start, after $12 \mathrm{~h}$ and again after $21 \mathrm{~h}$. The attached particles (fecal pellets, ciliates and different phytoplankton species) were enumerated under the inverted microscope. On each sampling occasion the sinking rate of houses was measured as above. We also measured the scavenging efficiency of 1 clean, $1.5 \mathrm{~mm}$ larvacean house produced by an Oikopleura dioica which had been kept in filtered sea water in the laboratory. The house contained 5 larvacean fecal pellets but was otherwise free of particles. A different procedure to that for the other houses was used: the house was released in an $80 \mathrm{~cm}$ transparent tube containing sub-surface sea water from the study site. The tube was closed and then turned upside down every time the house reached the bottom. After $1.8 \mathrm{~h}$ the house was collected together with $0.5 \mathrm{ml}$ of water with a wide-mouthed automatic pipette, and the number of Thalassiosira mendiolana cells was counted. Four additional $0.5 \mathrm{ml}$ samples were collected for counting of background concentrations of $T$. mendiolana. The sinking velocity was calculated from the number of turns.

Sediment traps. Sediment traps were deployed at $21 \mathrm{~m}$ depth. Each individual trap tube measured $65 \mathrm{~mm}$ in inner diameter, $675 \mathrm{~mm}$ in total height and had a detachable bottom section $85 \mathrm{~mm}$ in height. The top $90 \mathrm{~mm}$ consisted of 7 baffle tubes, each measuring $17.5 \mathrm{~mm}$ in inner diameter ( $21.5 \mathrm{~mm}$ in outer diameter). A varying number of baffle tubes were closed by stoppers to reduce the amount of material in the trap; from the area occluded by the stoppers we assumed that each stopped tube caused a $9 \%$ reduction of the vertical flux. Traps were retrieved every 12 or $24 \mathrm{~h}$.

Two trap tubes were each fitted with a petri dish (60 $\mathrm{mm}$ diameter) containing an $8 \%$ polyacrylicamid solution. This highly viscous polymer collects, preserves and retains the 3-dimensional structure of the sedimented material (Lundsgaard 1995). Thus, sedimenting aggregates remain intact. Upon retrieval, most water was siphoned from the tubes, the bottom section was detached, and remaining water was siphoned off using a micro-pipette. Material caught in the polymer was photographed with a Nicon camera equipped with a macro lens ( 2 to $20 \times$ magnification) using films for color slides. At $5 \times$ magnification we were able to obtain photographs covering the whole petri dish area. Later, the total number of aggregates was counted from projections of these slides. Aggregates larger than $0.1 \mathrm{~mm}$ in diameter were clearly distinguishable. In each sample the volumes of 35 to 100 random aggregates were calculated using close up photographs (20x magnification); from the projected aggregate area we measured 2 perpendicular radii and calculated the volume by assuming an ellipsoid shape for each aggregate. On April 23, larvacean 
Table 1 Oikopleura dioica. Average abundance between 0 and $20 \mathrm{~m}$ and mean trunk length \pm SD of animals as determined from bottle casts and net hauls with a net of $330 \mu \mathrm{m}$ mesh size. The concentrations and occupancy rates of larvacean houses are based on visual observations of indentifiable houses by divers in East Sound. nd = not determined

\begin{tabular}{|c|c|c|c|c|c|c|c|}
\hline \multirow{2}{*}{$\begin{array}{l}\text { Date } \\
\text { (April) }\end{array}$} & \multicolumn{2}{|c|}{ Abundance $\mathrm{m}^{-3}$} & \multirow[t]{2}{*}{$\%$ above $10 \mathrm{~m}$} & \multirow{2}{*}{$\begin{array}{c}\text { Trunk length }(\mu \mathrm{m}) \\
\text { net hauls }\end{array}$} & \multirow{2}{*}{$\begin{array}{l}\text { Depth } \\
(\mathrm{m})\end{array}$} & \multirow[t]{2}{*}{ Houses $\mathrm{m}^{-3}$} & \multirow[t]{2}{*}{$\%$ Occupied } \\
\hline & Net hauls & Bottle cast & & & & & \\
\hline 15 & 81 & 30 & 88 & $660 \pm 160$ & & nd & nd \\
\hline 16 & 49 & - & - & $720 \pm 150$ & & $\mathrm{nd}$ & nd \\
\hline 17 & 60 & - & - & $640 \pm 170$ & & nd & nd \\
\hline 18 & 60 & - & - & $740 \pm 180$ & & nd & nd \\
\hline 19 & 50 & 191 & 81 & $690 \pm 130$ & & nd & nd \\
\hline 19.5 & 117 & - & - & $660 \pm 160$ & & nd & nd \\
\hline 20 & 38 & 86 & 86 & $630 \pm 130$ & & nd & nd \\
\hline 20.5 & 64 & 93 & 93 & $650 \pm 150$ & & nd & nd \\
\hline \multirow[t]{3}{*}{21} & 85 & 160 & 96 & $670 \pm 170$ & 5 & $100 \pm 20$ & $63 \pm 3$ \\
\hline & & & & & 10 & $500 \pm 200$ & $28 \pm 4$ \\
\hline & & & & & 20 & $600 \pm 100$ & nd \\
\hline \multirow[t]{3}{*}{23} & 80 & 99 & 88 & $670 \pm 180$ & 5 & $800 \pm 100$ & nd \\
\hline & & & & & 10 & $3700 \pm 900$ & nd \\
\hline & & & & & 20 & $4800 \pm 900$ & nd \\
\hline 24 & 28 & 80 & 77 & $760 \pm 1.40$ & & nd & nd \\
\hline Mean & $65 \pm 24$ & $118 \pm 42$ & $87 \pm 6$ & $680 \pm 40$ & & & \\
\hline
\end{tabular}

houses were collected by divers and allowed to settle in a petri dish filled with polymer to be compared with the aggregates from the sediment traps. After approximately 2 h of settling, the size distribution was measured as above. Daily fluxes of larvacean houses were calculated from the number of aggregates $>0.3 \mu \mathrm{l}$, i.e. aggregates of sizes equivalent to those of the divercollected houses (see below). Daily aggregate volume fluxes were calculated from the average aggregate size of each sample.

From each petri dish, 2 to 8 aggregates were sampled individually from the polymer with a specially designed pipette mounted on a syringe. Formalin was added to the aggregate samples, which contained 10 to 20 jul polymer, for a final concentration of $2 \%$; samples were then spread on a microscope slide and sealed under a cover slide with fingernail polish. Later, the contents of the aggregates (selected phytoplankton species and fecal pellets) were counted at $200 \times$ magnification.

\section{RESULTS}

\section{Abundance of larvaceans}

The larvacean Oikopleura dioica was abundant throughout the study period and occurred in more or less constant densities. Vertical net hauls showed an average water column concentration of 65 larvaceans $\mathrm{m}^{-3}$ (Table 1). Sampling with water bottles indicated that net hauls underestimated the densities of larvaceans, because small individuals passed through the $333 \mu \mathrm{m}$ mesh size net, and also revealed that $87 \%$ of the larvaceans occurred in the upper $10 \mathrm{~m}$. The sizes of the net-captured larvaceans did not vary significantly; mean trunk length was $680 \mu \mathrm{m}$ (Table 1) while the average bottle-collected larvaceans were slightly smaller, $595 \pm 63 \mu \mathrm{m}$. Abandoned houses of $O$. dioica were always present in the water column. Divers found an average water column concentration of 383 houses $\mathrm{m}^{-3}$ on April 21 and 2978 houses $\mathrm{m}^{-3}$ on April 23, and the density generally increased with depth. The occupancy rate was $68 \%$ at $5 \mathrm{~m}$ depth and $28 \%$ at $10 \mathrm{~m}$ depth on April 21 (Table 1).

\section{Size distribution and flux of larvacean houses}

The sediment traps collected aggregates throughout the study period. Microscopical examination of aggregates trapped in the polymer revealed that the majority of settled aggregates were abandoned larvacean houses, or fragments of houses, containing amorphous detritus, fecal pellets and phytoplankton cells. Some aggregates could only be recognized as detritus but their shape was very similar to that of larvacean houses collected by divers and subsequently allowed to settle in the polymer. Larvacean houses collected by divers covered a size range of 0.8 to $1.9 \mathrm{~mm}$ equivalent spherical diameter (ESD) or 0.3 to $3.5 \mu \mathrm{l}$. The size distribution (volume) of diver-collected houses conformed with 

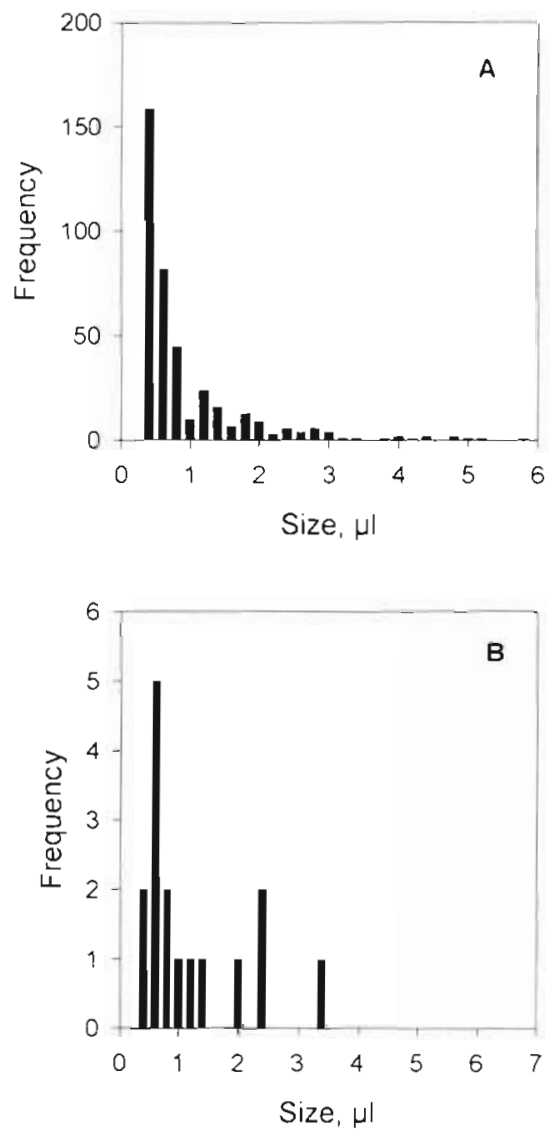

Fig. 2. Frequency distribution of aggregates and Oikopleura dioica houses obtained from umage analysis: (A) aggregates larger than $0.3 \mu$ l collected in sediment traps from April 16 to 24 , $(n=314)$, (B) Larvacean houses collected from the water column by divers and subsequently allowed to settle in polymer $(n=16)$

the size distribution of all settled aggregates (April 14 to 24 ) larger than $0.3 \mu$ l (Fig. 2) ( $t$-test, $p>90 \%$ ). The average size of larvacean houses was $1.21 \mathrm{~mm}$ ESD and average size of aggregates $>0.3 \mu$ collected in traps was $1.13 \mathrm{~mm}$ ESD. Thus, we considered all aggregates $>0.3 \mu$ to be larvacean houses.

The flux of houses was on average 55000 houses $\mathrm{m}^{-2}$ $\mathrm{d}^{-1}$, with a maximum value of 116000 houses $\mathrm{m}^{-2} \mathrm{~d}^{-1}$ (Fig. 3). These numbers correspond to average and peak aggregate volume fluxes of $48 \mathrm{ml} \mathrm{m}^{-2} \mathrm{~d}^{-1}$ and $128 \mathrm{ml} \mathrm{m}^{-2} \mathrm{~d}^{-1}$.

\section{Sinking rates}

The grand mean of all sinking velocities measured in the laboratory was $121 \mathrm{~m} \mathrm{~d}^{-1}$ (Table 2). Diver-collected larvacean houses settled at $137 \pm 50 \mathrm{~m} \mathrm{~d}^{-1}(\mathrm{n}=12)$. Houses aged for $21 \mathrm{~h}$ on the rolling table settled at $69 \pm$ $35 \mathrm{~m} \mathrm{~d}^{-1}$ and the control group at $138 \pm 51 \mathrm{~m} \mathrm{~d}^{-1}$. One clean, $1.5 \mathrm{~mm}$ diameter house produced in the labora-

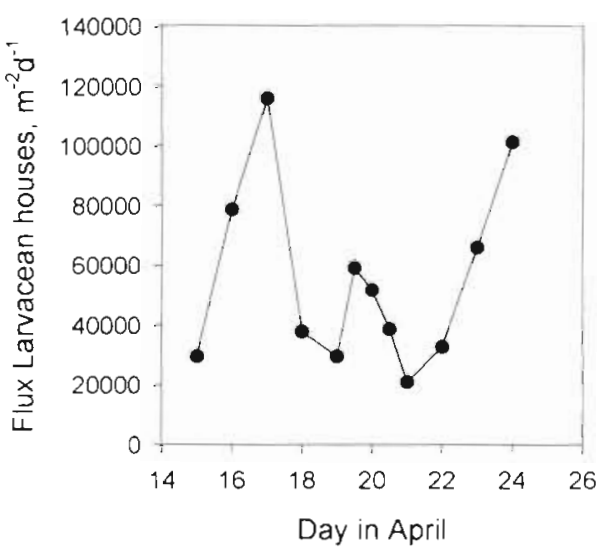

Fig. 3. Daily flux of abandoned Oikopleura dioica houses (= aggregates larger than $0.3 \mu l$ )

tory settled at $115 \mathrm{~m} \mathrm{~d}^{-1}$. Sinking velocities did not correlate with numbers of attached fecal pellets and diatoms.

\section{House production rate}

Oikopleura dioica incubated in the laboratory at $12^{\circ} \mathrm{C}$ in sea water from East Sound produced $7.2 \pm$ 1.6 houses $\mathrm{d}^{-1}$.

\section{Particle content of larvacean houses}

\section{Aggregates in traps}

Attached particles could easily be specified and counted on aggregates sampled in the polymer. The aggregates contained high numbers of diatoms, flagellates, ciliates and fecal pellets. The content of Thalassiosira mendiolana per aggregate increased from $<50$ in the beginning of the study to $>250$ at the end. The abundance of Thalassionema nitschioides also increased 5 times during the period to about 600 cells per aggregate. In

Table 2. Sinking velocities of larvacean houses measured in a graduated cylinder or in an $80 \mathrm{~cm}$ long transparent tube Number of houses measured shown in parentheses

\begin{tabular}{|lc|}
\hline Description of houses & $\begin{array}{c}\text { Sinking rate } \\
\mathrm{m} \mathrm{d}^{-1} \pm \mathrm{SD}\end{array}$ \\
\hline Houses collected in situ (12) & $137 \pm 50$ \\
Houses aged for 21 h on rolling table (7) & $69 \pm 35$ \\
Houses in standing jars (11) & $138 \pm 51$ \\
House produced in the laboratory (1) & 115 \\
Mean & 121 \\
\hline
\end{tabular}



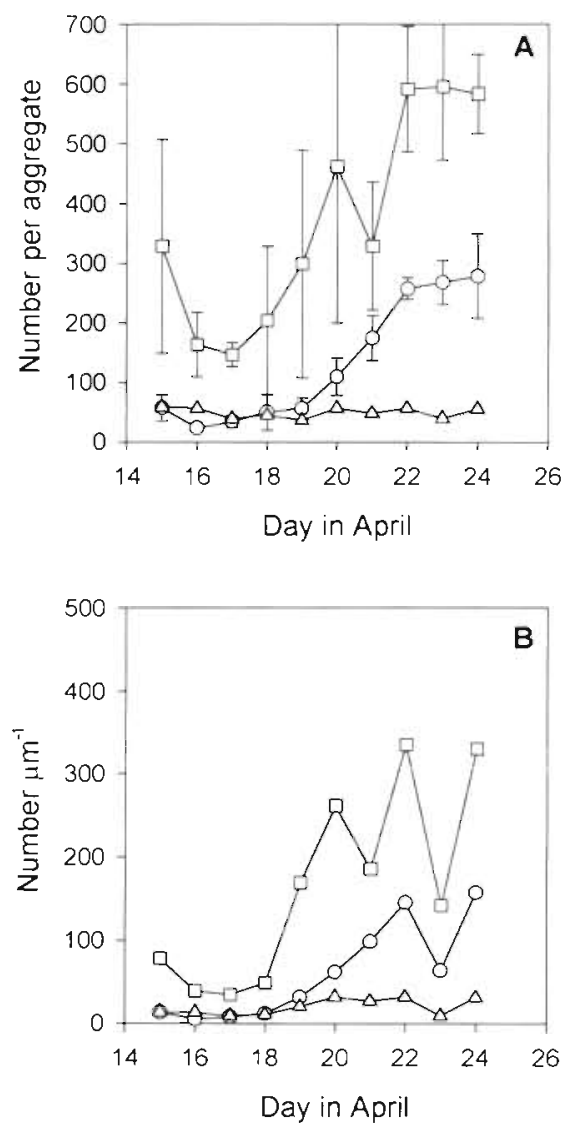

Fig. 4. Contents of diatoms and fecal pellets in aggregates collected in sediment traps. (A) Number per aggregate $(n=2$ to 6 per sampling date). (B) number per aggregate volume (ㅁ) Thalassionema nitschioides, (O) Thalassiosira mendiola, $(\Delta)$ fecal pellets

contrast, the content of fecal pellets remained constant at about 50 pellets per aggregate (Fig. $4 \mathrm{~A}$ ). The number of particles per aggregate volume followed the same pattern (Fig. 4B). Increasing numbers of diatoms ( $T$. mendiolana, T. nitschioides) were closely related to increasing concentrations of these species in the water column, where a diatom bloom was developing. The relationship between bulk water concentration and diatom content of aggregates was given by a first order function (Fig. 5A). On average for the whole study period each aggregate coniained these diatoms in abundances corresponding to those found in $4.55 \mathrm{ml}$ of ambient water (Fig. 5B). Inside the aggregates, diatom concentrations were 1000 times higher than in ambient water. Aggregates were even more enriched in fecal pellets, with concentrations 100000 times higher than in the surrounding water, corresponding to a 'cleared volume' of $100 \mathrm{ml}$ for each aggregate, which refers to the volume of ambient water containing the same number of particles as 1 aggregate
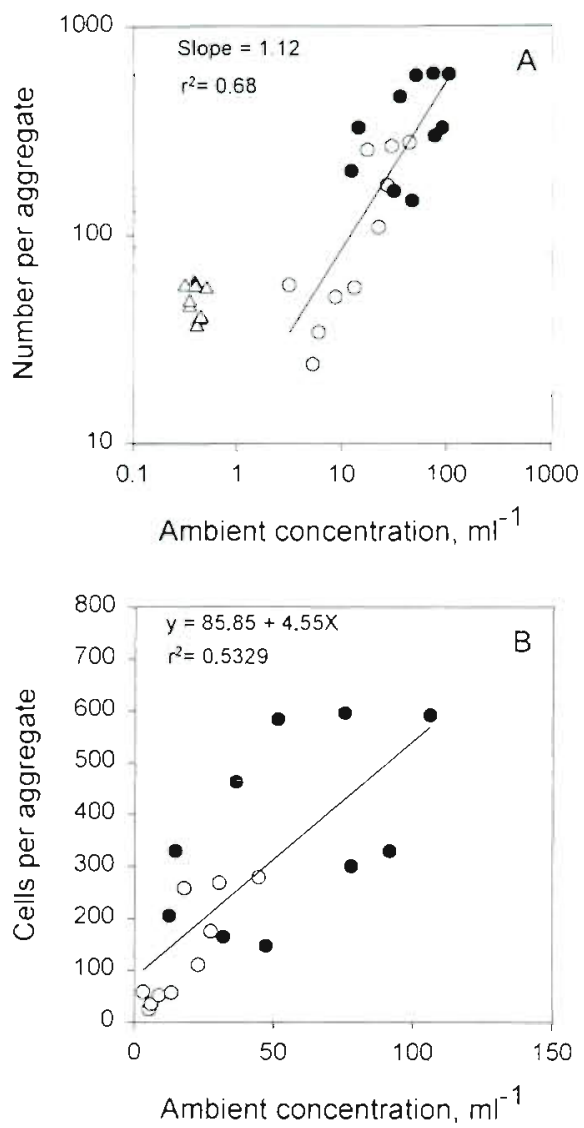

Fig. 5. Trap-collected aggregates: (A) number of particles per aggregate versus water coiumn concentration (mean of concentration at ca 5 and $21 \mathrm{~m}$ depth), linear regression $(\mathrm{n}=19\}_{\text {; }}$ (B) as (A) but on a Iinear scale and without fecal pellets. (-) Thalassionema nitschioides, (O) Thalassiosira mendiola, $(\Delta)$ fecal pellets

\section{Diver-collected aggregates}

Suspended larvacean houses carried particle assemblages similar to those carried by houses collected in the traps. A large number of diatom species, fecal pellets and ciliates were found on the houses (Table 3). There was no consistent temporal pattern in aggregate enrichment from April 19 to 24 (Table 4). Larvacean houses sampled at $10 \mathrm{~m}$ depth seemed to be more enriched than those from 5 and $20 \mathrm{~m}$ but the background concentration was obtained from interpolation of concentrations at 5 and $21 \mathrm{~m}$ and thus the pattern was not conclusive. The number of attached diatoms averaged $2140 \pm 1086$ cells house ${ }^{-1}$, equal to the content in $4.47 \mathrm{ml}$ of ambient water; this is similar to the above estimate ( $4.55 \mathrm{ml} \mathrm{house}^{-1}$ ) based on trap-collected houses. Total content of diatoms in houses followed the water column concentrationi a plot (Fig. 6) based on abundances of individual diatom species yields a significant relation (linear regression: $\mathrm{n}=212$, 
Table 3. Average number of diatoms, flagellates, cillaates and fecal pellets attached to larvacean houses collected from 5 to $20 \mathrm{~m}$ by divers between April 19 and 24. Total sample size is 14 , each containing 10 to 100 houses $[\mathrm{n}$ (total) $=316]$. Data from Kiorboe et al. (1996)

\begin{tabular}{|lcc|}
\hline Type of particle & $\begin{array}{c}\text { Number of } \\
\text { species }\end{array}$ & $\begin{array}{c}\text { Cells per } \\
\text { house }\end{array}$ \\
\hline Diatoms & & \\
Chaetoceros sp. & 10 & 63 \\
Ditylum brightwellii & - & 6.3 \\
Laudania annulata & - & 28 \\
Leptocylindrus danicus & - & 32 \\
Navicula sp. & 1 & 15 \\
Nitzschia sp. & 2 & 312 \\
Pseudonitzschia sp. & 2 & 81 \\
Rhizosolenia sp. & 6 & 296 \\
Skeletonema costatum & - & 15 \\
Thalassionema nitschioides & - & 800 \\
Thalassiosira sp. & 4 & 474 \\
Dictyocha speculum & - & 23 \\
Phaeocystis pouchetii & - & 1211 \\
Fecal pellets & - & 42 \\
Oligotrich ciliates & - & 12 \\
\hline
\end{tabular}

$t=3.34, \mathrm{p}<0.1 \%)$ in spite of a considerable scatter $\left(\mathrm{r}^{2}=\right.$ $0.053)$, and the slope of the relation, $5.32 \pm 0.68 \mathrm{ml}$ house $e^{-1}$, is again similar to the above estimates. Again houses were more enriched with fecal pellets than with diatoms, with an average of $47 \pm 56$ pellets per house corresponding to the fecal pellet content of $42 \pm 43 \mathrm{ml}$ of ambient water; this is of a similar order of magnitude as the $100 \mathrm{ml}$ house ${ }^{-1}$ estimated for the trap samples.

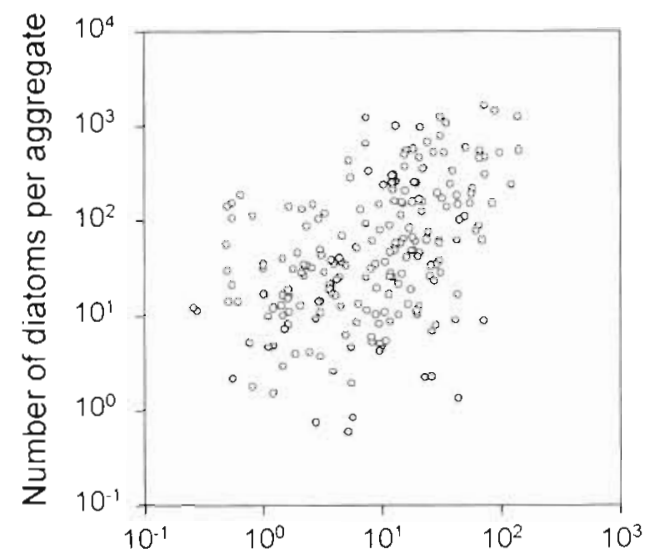

Ambient diatom concentration, $\mathrm{ml}^{-1}$

Fig. 6. Diver-collected aggregates: number of diatoms per aggregate versus concentration in ambient water. Each data point represents 1 diatom species on 1 sampling day

The considerable variation in the numbers of attached particles in diver-collected houses may be caused by differences in their age. For example, some houses were still occupied when collected, while others obviously had been abandoned for some time.

\section{Particle scavenging by settling larvacean houses}

Larvacean houses incubated on the rolling table contained more of all groups of particles than did the controls (Table 5). Thus, larvacean houses do scavenge

Table 4. Amounts of fecal pellets and diatoms in larvacean houses collected at various depths. 'Volume cleared' is the calculated volume of ambient water containing the same number of particles as 1 larvacean house. Estimates of volume cleared at $10 \mathrm{~m}$ depth were based on the average of ambient concentrations at 5 and $21 \mathrm{~m}$. Data on ambient concentrations of fecal pellets and diatoms are from Kiorboe et al. (1996)

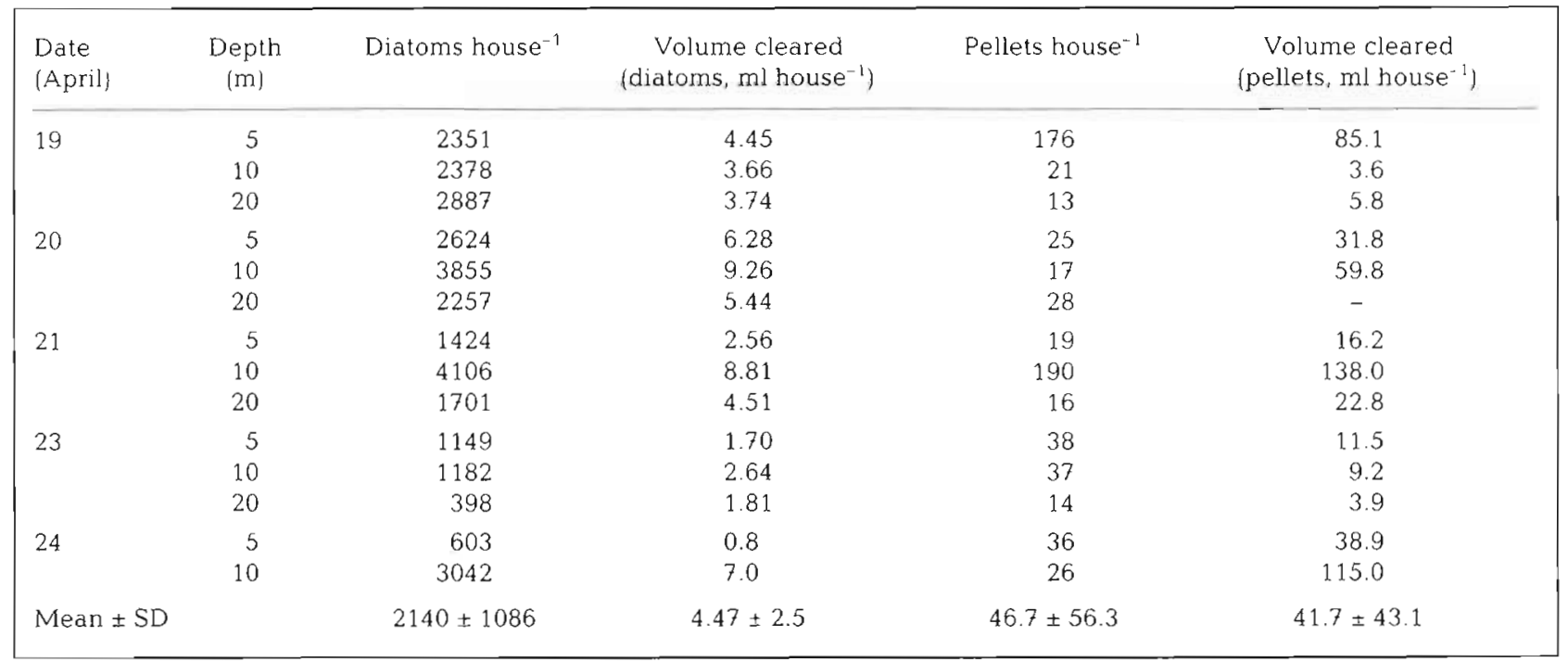


Table 5. Particle scavenging by sinking larvacean houses. Diver-collected larvacean houses from $10 \mathrm{~m}(\mathrm{n}=20)$ uncubated in water from $5 \mathrm{~m}$ on a rolling table. Another 20 houses were incubated in a standing jar (control). Aggregates were sampled after 12 and $21 \mathrm{~h}$ and attached particles were counted and identified. Table shows average number per aggregate and number of houses sampled

\begin{tabular}{|c|c|c|c|c|c|}
\hline & \multicolumn{2}{|c|}{ After $12 \mathrm{~h}$} & \multicolumn{2}{|c|}{ After $21 \mathrm{~h}$} & \multirow{2}{*}{$\begin{array}{l}\text { Conc. in ambient wate } \\
\qquad\left(\mathrm{ml}^{-1}\right)\end{array}$} \\
\hline & Rolling table & Control & Rolling table & Control & \\
\hline Number of houses & 1 & 8 & 5 & 6 & - \\
\hline Fecal pellets & 16.1 & $3.9 \pm 2.0$ & $25 \pm 23$ & $9.3 \pm 2.9$ & 0.44 \\
\hline Ciliates & 10.0 & $2.2 \pm 1.0$ & $23 \pm 20$ & $4.0 \pm 7.5$ & - \\
\hline Thalassionema sp. (chains) & 42.6 & $8.7 \pm 4.4$ & $52 \pm 34$ & $9.7 \pm 6.5$ & - \\
\hline Chaetoceros sp. (chains) & 40.9 & $16.2 \pm 14$ & - & - & - \\
\hline Thalassiosira sp. (chains) & 9.8 & $5.5 \pm 4.3$ & - & - & - \\
\hline Phaeocystis (colonies) & 2.4 & $1.5 \pm 1.9$ & - & - & - \\
\hline Thalassiosira mendiolana & 14.1 & $06.7 \pm 13.7$ & $32 \pm 17$ & $12.5 \pm 7.0$ & 12.3 \\
\hline
\end{tabular}

particles as they settle. We quantified scavenging as a clearance rate, i.e. as the volume of ambient water cleared for particles per unit time $=$ (difference in particles per house in the control and the experimental container)/incubation time/ambient concentration. From Table 5 we estimate that Thalassiosira mendiolana cells were cleared at a rate of $0.06 \pm 0.01 \mathrm{ml}$ house $\mathrm{e}^{-1} \mathrm{~h}^{-1}$ while fecal pellets were cleared at a rate of $2.0 \pm 0.4 \mathrm{ml}$ house $\mathrm{e}^{-1} \mathrm{~h}^{-1}$ in the rolling table. The larvacean house settling for $1.8 \mathrm{~h}$ in the reverting tube at an ambient concentration of $58 \pm 14 T$. mendiolana cells $\mathrm{ml}^{-1}$ collected 4 cells; this yields a clearance rate of $0.06 \pm 0.08 \mathrm{ml} \mathrm{h}^{-1}$, consistent with the above.

The relatively higher uptake rate of fecal pellets than diatoms in the experiments agrees well with observations of larvacean houses from both the water column and the sediment traps. However, scavenging rates obtained in the laboratory cannot explain the observed particle content of the houses; if larvacean houses settle at $100 \mathrm{~m} \mathrm{~d}^{-1}$ they will on average spend 2 to $3 \mathrm{~h}$ in the water column above the trap depth after being abandoned. Thus, expected diatom and fecal pellet abundances in houses due to this mechanism would correspond to the contents in 0.15 and $5 \mathrm{ml}$ of ambient water, respectively. This is about 20 times less than observed.

\section{DISCUSSION}

The fragile nature of marine aggregates normally causes them to disintegrate in sediment trap samples. In this study, the polymer in the traps enabled us to demonstrate, for the first time, that marine aggregates found suspended in the water column were similar to aggregates simultaneously collected in sediment traps. Not only were the size distributions similar (Fig. 2), but the quantities of diatoms and fecal pellets found in aggregates were almost identical between those col- lected in the water column and those collected in the traps. In the present case most aggregates turned out to be discarded larvacean houses. Dense populations of the larvacean Oikopleura dioica have earlier been observed to cause high concentrations of suspended aggregates (Alldredge 1979), and there are several previous observations that the gelatinous structures of the house form the matrices of aggregates carrying numerous phytoplankton cells, ciliates, fecal pellets and amorphous detritus (Alldredge 1972, 1976 , Taguchi 1982, Davoll \& Silver 1986). Alldredge \& Silver (1988) concluded that whenever larvaceans are present they form an important source of marine snow. In East Sound we observed that the fate of these aggregates was sedimentation, as they totally dominated the flux of aggregates.

\section{Dynamics and settling of discarded larvacean houses}

The net hauls probably undersampled the smaller Oikopleura dioica and, consequently, the population estimates based on net hauls are smaller than those estimated by water bottles or divers (Table 1) and do not compare with house fluxes, as observed in the sediment traps. On April 21, divers counted 300 to 400 houses $\mathrm{m}^{-3}$ above the depth of the traps. Between 16 and $31 \%$ of these houses were occupied (Table 1; assuming an occupation ratio between 0 and $28 \%$ at $20 \mathrm{~m}$ depth), meaning that the abundance of abandoned houses was about 300 houses $\mathrm{m}^{-3}$. That particular day the flux of houses was $27000 \mathrm{~m}^{-2} \mathrm{~d}^{-1}$ (average for April 21 and 22). At steady state, these numbers suggest an average in situ sinking velocity of $(27000$ houses $\mathrm{m}^{-2} \mathrm{~d}^{-1} / 300$ houses $\left.\mathrm{m}^{-3}=\right) 90 \mathrm{~m} \mathrm{~d}^{-1}$. A similar calculation for April 23 and 24 yields $41 \mathrm{~m} \mathrm{~d}^{-1}$ (assuming an occupation ratio of $31 \%$ ). These numbers agree reasonably well with our laboratory measurements (69 to $138 \mathrm{~m} \mathrm{~d}^{-1}$ ) and with Gorsky et al. (1984), who 
found settling velocities of 26 to $157 \mathrm{~m} \mathrm{~d}^{-1}$ of $O$ dioica houses. These sinking rates imply that, after being abandoned, the houses are exported out of the euphotic zone within 2 to $3 \mathrm{~h}$ and the standing stock in the water column turns over 4 to 5 times $\mathrm{d}^{-1}$ Because the houses turn over rapidly in the water column we can calculate the average in situ house production rate from house flux divided by the population size of animals above the trap depth; i.e. 27000 houses $\mathrm{m}^{-2}$ $\mathrm{d}^{-1} / 160$ animals $\mathrm{m}^{-3} / 21 \mathrm{~m}=8$ houses animal $\mathrm{l}^{-1} \mathrm{~d}^{-1}$. The same calculation gives a house production rate of 25.7 houses animal ${ }^{-1} \mathrm{~d}^{-1}$ on April 23. Although a bit high, these values are comparable to our laboratory measurement of 7.2 houses animal ${ }^{-1} \mathrm{~d}^{-1}$. Literature values of house production rates range from a few houses per day to $>16$ houses animal ${ }^{-1} \mathrm{~d}^{-1}$ (Gorsky et al. 1984, Fenaux 1985). At a comparable temperature $\left(15^{\circ} \mathrm{C}\right)$ Fenaux (1985) found a production rate of 7.5 houses animal ${ }^{-1} \mathrm{~d}^{-1}$ in $O$. dioica.

\section{Mechanisms of aggregation}

Our data consistently suggest that: (1) composition and abundance of particles attached to larvacean houses are related to ambient particle composition and abundance, (2) diatom abundance in the aggregates corresponds to a 'cleared' ambient volume of 4 to $5 \mathrm{ml}$ while (3) fecal pellet abundance in aggregates corresponds to 50 to $100 \mathrm{ml}$ of ambient water. There are a number of mechanisms by which suspended particles can become attached to larvacean houses. The larvacean itself produces fecal pellets while inhabiting the house and these remain inside the discarded house (Taguchi 1982). Larvacean pellets resemble copepod fecal pellets, and could not be distinguished. In fact, the number of fecal pellets per house found here ( $\mathrm{ca}$ 50) is similar to the number of pellets left in discarded houses by Oikopleura longicauda (Taguchi 1982), and are most likely due to the animal itself. For the rest of the attached particles there are several possible mechanisms involved in bringing them into physical contact with the house. Obviously, self-motile cells can actively colonize the houses and may explain the association of cliates with the houses. Large diatoms may be captured on the coarse incurrent filter while the house is still inhabited (Paffenhöffer 1973, Alldredge 1977, Davoll \& Silver 1986) thereby forming an aggregate prior to abandonment. In fact, clogging of filters has been invoked as the cause of house renewal (Alldredge 1977). After being discarded, these relatively fast settling houses may scavenge suspended particles on their way through the water column as hypothesised by Morris et al. (1988). Finally abandoned houses may be brought into contact with suspended particles by shear in the water column.

The efficiency of shear coagulation can be examined theoretically. Assume that an abandoned house can be considered a solid sphere. Then a house collides with suspended particles occurring at concentration $C$, according to Hill (1992):

$$
\text { Collision rate }=\beta_{\text {Shear }} E_{\text {Shear }} C
$$

where $\beta_{\text {shear }}$ is the collision kernel for shear coagulation:

$$
\beta_{\text {Shear }}=0.163 \gamma\left(d_{1}+d_{j}\right)^{3}
$$

where $\gamma$ is the shear rate; and $E_{\text {Shear }}$ is the contact efficiency of unlike sized solid particles:

$$
E_{\text {Shear }}=7.5\left(d_{i} / d_{j}\right)^{2}\left(1+2 d_{j} / d_{j}\right)^{-2} \quad \text { for } d_{i}<d_{j}
$$

where $d$, is the diameter of the house and $d_{1}$ is the diameter of the suspended particles. The volume cleared $(V)$ by each house is:

$$
V=E_{\text {Shear }} \beta_{\text {Shear }} t
$$

where $t$ is the time needed for each house to travel through the water column. The mean vertical current shear rate in East Sound ranged from about $0.01 \mathrm{~s}^{-1}$ to slightly more than $0.02 \mathrm{~s}^{-1}$ during the study period, (Kiørboe et al. 1996). Since there was hardly any wind during the study period, wind generated turbulence would be insignificant. Assuming $\gamma=0.02 \mathrm{~s}^{-1}$, then a $1 \mathrm{~mm}$ house sinking $100 \mathrm{~m} \mathrm{~d}^{-1}$ in a suspension of $100 \mu \mathrm{m}$ diatoms will theoretically clear $0.004 \mathrm{ml}$ of ambient water before reaching the sediment trap. Even if we ignore the hydrodynamic effect (i.e. set $E_{\text {Shear }}=1$ ), which is equivalent to assuming that the house is infinitely permeable (Stoltzenbach 1993), then the estimated volume cleared would increase to $0.08 \mathrm{ml}$. This is small compared to the 4 to $5 \mathrm{ml}$ actually observed and we conclude that shear coagulation contributes insignificantly to aggregate enlargement.

The efficiency of scavenging can be examined in a similar way by replacing the expressions for $\beta$ and $E$ in Eq. (1) as follows (Hill 1992):

$$
V=\beta_{\text {Senting }} E_{\text {Settling }} t
$$

where $\beta_{\text {Settlng }}$ is the coagulation kernel for differential settling of particles having settling velocities $v_{1}$ for the suspended particles and $v_{j}$ for the house and $E_{\text {Settling }}$ is the contact efficiency of solid settling particles:

$$
\begin{aligned}
& \beta_{\text {Settling }}=(\pi / 4)\left(d_{i}+d_{j}\right)^{2}\left|v_{1}-v_{j}\right| \\
& E_{\text {Settling }}=\left(d_{i} / d_{j}\right)^{2} / 2\left[1+\left(d_{i} / d_{j}\right)\right]^{2}
\end{aligned} \quad \text { for } d_{i}<d_{j}
$$

Eq. (2) then reduces to:

$$
V=(\pi / 8) d_{i}^{2}\left|V_{1}-v_{j}\right| t
$$

If the large particle sinks much faster than the small one $\left(v_{1} \ll v_{j}\right)$ then $\left|v_{1}-v_{j}\right| \approx v_{j}$. Because $v_{j} \times t$ is the depth 
$(z)$ of the water column, the cleared volume per house is calculated from:

$V=(\pi / 8) d_{1}^{2} z \quad$ (for solid particles)

$V=(\pi / 4)\left(d_{l}+d_{i}\right)^{2} z$ (for permeable particles, $E=1$ )

Eq. (3) shows that the scavenging efficiency does not depend on the size or settling velocity of the sinking particle (i.e. the larvacean house), whereas the size of the smaller particles is critical. For example, a larvacean house sinking a distance of $10 \mathrm{~m}$ through a suspension of $100 \mu \mathrm{m}$ diatoms (e.g. Thalassiosira mendiola) would clear $0.04 \mathrm{ml}$ of ambient water before reaching the sediment trap. This is about 2 orders of magnitude less than the 4 to $5 \mathrm{ml}$ house ${ }^{-1}$ estimated for field-collected houses but similar to the scavenging rates actually observed in the laboratory experiments (Table 6). By ignoring hydrodynamic effects $(E=1)$ this estimate increases to $9.5 \mathrm{ml}$ house $^{-1}$ for a $1 \mathrm{~mm}$ house. However, our scavenging experiments yielded rates which suggest that settling houses behave more like solid than permeable particles (Table 6). The experiments also showed that the larger fecal pellets were scavenged about 30 times faster than diatoms, which is predicted from Eq. (3) if the fecal pellets are about 5 times larger than the diatoms. In contrast, a permeable house would scavenge diatoms and fecal pellets at about the same rate as long as the house is much larger than the particles being scavenged (Eq. 4). These findings are consistent with the non-porous mucous membrane surrounding the house. Trap-collected houses did not carry more particles than those collected in the water column, and particle loading did not increase with collection depth as expected if scavenging was important. Thus, observations, experiments, and theory suggest particle scavenging to be of secondary importance.

By filtering alone, each animal should filter about $35 \mathrm{ml} \mathrm{d}^{-1}$ in order to fill 7.2 houses with the observed number of diatoms. According to Paffenhöfer (1975) an animal with a trunk length of $680 \mu \mathrm{m}$ filters about $65 \mathrm{ml} \mathrm{d}^{-1}$ at $13^{\circ} \mathrm{C}$ (the surface temperature at the study site was 11 to $12^{\circ} \mathrm{C}$. The length-grazing rate regression of Oikopleura dioica from King et al. (1980) predicts a filtering rate of $21 \mathrm{ml} \mathrm{d}^{-1}$ at $13.5^{\circ} \mathrm{C}$, and according to Alldredge (1981) individuals of this size filter about $121 \mathrm{ml} \mathrm{d}^{-1}$ at $23^{\circ} \mathrm{C}$. Thus, filtering rates reported in the literature appear sufficient to account for the observed abundance of diatoms attached to discarded larvacean houses.

We conclude that the feeding activity of Oikopleura dioica itself is the most important mechanism for aggregation of parti- cles onto the houses. Once these impermeable houses become abandoned further collection of particles by scavenging and shear coagulation is insignificant, and their presence in the water column has no quantitative effect on the overall aggregation processes. In fact, the daily flux of houses in East Sound would theoretically scavenge less than $0.1 \%$ of the $100 \mu \mathrm{m}$ diatom population per day and only $0.001 \%$ of the $10 \mu \mathrm{m}$ size fraction.

By comparison, if the aggregate flux in East Sound had been composed of diatom aggregates, which are known to be highly permeable (Logan \& Alldredge 1989), the sinking aggregates would on average scavenge $5.2 \% \mathrm{~d}^{-1}$ laverage flux multiplied by cleared volume per aggregate (Eq. 4): $0.95 \mathrm{ml}$ house $\mathrm{e}^{-1} \mathrm{~m}^{-1} \times 55000$ houses $\mathrm{m}^{-2} \mathrm{~d}^{-1}=52300 \mathrm{ml} \mathrm{m}^{-3}$ ) of the particles in the entire water column including the smallest size fraction. This last example serves to highlight the general imporlance of the structure (permeability) of marine snow and, thus, of the origin of the marine snow particles, especially in a deep water column.

\section{Significance of larvacean houses in the pelagic food web}

Marine snow particles are recognized as sites of elevated microbial activity (Alldredge \& Cox 1982, Alldredge \& Silver 1988), and Davoll \& Silver (1986) described how the developing microbial community on a discarded larvacean house causes its disintegration within about a week. However, in shallow waters like

Table 6 . Volumes cleared of diatoms by larvacean houses as estimated by different approaches: field observations, experiments, and theoretically due to various coagulation mechanisms. The experimental value $\left(0.06 \mathrm{ml} \mathrm{h}^{-1}\right)$ has been converted to the volume cleared during the expected average residence time of an abandoned larvacean house in the upper $20 \mathrm{~m}$ of the water column $(3 \mathrm{~h})$. Theoretical values are calculated for a $1 \mathrm{~mm}$ diameter larvacean house settling at $100 \mathrm{~m} \mathrm{~d}^{-1}$ in a suspension of $100 \mu \mathrm{m}$ diameter diatom cells. The houses are assumed to be either porous or non-porous

\begin{tabular}{|c|c|c|}
\hline Observations/mechanisms & Equation & $\begin{array}{l}\text { Cleared volume } \\
\left(\mathrm{ml} \text { house } \mathrm{e}^{-1}\right)\end{array}$ \\
\hline \multicolumn{3}{|l|}{ Observed in situ } \\
\hline Houses in traps & - & 4.55 \\
\hline Houses in suspension & - & 4.47 \\
\hline \multicolumn{3}{|l|}{ Experiment } \\
\hline Scavenging of diatoms & - & 0.07 \\
\hline \multicolumn{3}{|l|}{ Theoretical } \\
\hline \multicolumn{3}{|l|}{ Scavenging } \\
\hline Porous & $\beta_{\text {Seming }} t$ & 9.50 \\
\hline Non-porous & $\beta_{\text {Settung }} E_{\text {Settling }} t$ & 0.04 \\
\hline \multicolumn{3}{|c|}{ Shear coagulation $\left(\gamma=0.02 \mathrm{~s}^{-1}\right)$} \\
\hline Porous & $\beta_{\text {Shear }} t$ & 0.08 \\
\hline Non-porous & $\beta_{\text {Shedr }} E_{\text {Shear }} t$ & 0.004 \\
\hline
\end{tabular}


East Sound, discarded houses reach the sea floor in a few hours, and in such areas the most important role of abandoned larvacean houses appears to be their contribution to the vertical flux of organic material. Since scavenging and shear coagulation are unimportant as mechanisms of aggregation, the house production rate of Oikopleura dioica affects only the volume flux of marine snow, whereas the flux of attached particles depends solely on the filtration rate of the larvacean. By its feeding current each larvacean daily collects an amount of particulate material corresponding to the pumping rate multiplied by the ambient concentration of particles. This material is transformed into fast sinking aggregates due to fecal pellet production (Pomeroy $\&$ Deibel 1980) and collection on the house. Thus, functionally the entire abandoned house resembles sinking fecal pellets of other zooplankters. However, as the larvaceans consume only a certain size spectrum, they may cause much more organic material to settle undigested from the euphotic zone than they actually consume and this material includes live phytoplankton.

Although the abundance of larvaceans in this study suggests a rather limited effect on the sedimentation rate of the phytoplankton (Kiørboe et al. 1996), the observed flux of live diatoms was mainly due to cells attached to larvacean houses (Kiorboe et al. 1996). Since larvaceans may occur in dense swarms exceeding $10000 \mathrm{~m}^{-3}$ (Seki 1973), abandoned larvacean houses may at times account for a significant fractional removal rate of large particles from the euphotic zone, and they appear to be one of the several mechanisms behind the rapid fallout of live phytoplankton sometimes seen during diatom blooms.

Acknowledgements. We are grateful to the captain and crew of RV 'Barnes' and to the staff of the Friday Harbor Laboratories for their help during the study. We are also thankful for the technical help of C. Gotschalk, D. Gedde and O. Vestergaard. This study was supported by grants from the Danish Science Research Council (11-0420-1) and the U.S. Office of Naval Research (N00014-93-1-0226, N00014-87-K0005) to T.K. and A.L.A.

\section{LITERATURE CITED}

Alldredge AL (1972) Abandoned larvacean houses: a unique food source in the pelagic environment. Science 177:885-887

Alldredge AL (1976) Discarded appendicularian houses as sources of food, surface habitats, and particulate organic matter in planktonic environments. L.mnol Oceanogr 21(1):14-23

Alldredge AL (1977) House morphology and mechanisms of feeding in the Oikopleuridae (Tunicata, Appendicularia). J Zool Lond 181:175-188

Alldredge AL (1979) The chemical composition of macroscopic aggregates in two neritic seas. Limnol Oceanogr 24(5):855-866

Alldredge AL (1981) The impact of appendicularian grazing on natural food concentrations in situ. Limnol Oceanogr
$26(2): 247-257$

Alldredge AL (1992) In situ collection and laboratory analysis of marine snow and large fecal pellets. In: Hurd DC, Spencer DW (eds) Geophysical Monograph 63. Marine particles: analysis and characterization. American Geophysical Union, Washington, DC, p 43-46

Alldredge AL, Cox JL (1982) Primary productivity and chemical composition of marine snow in surface waters of the Southern Californı Bight. J Mar Res 40(2):517-527

Alldredge A.L, Silver MW (1988) Characteristics, dynamics and signiticance of marine snow. Prog Oceanogr 20:41-82

Bathmann UV, Noji TT, von Bodungen B (1991) Sedimentation of pteropods in the Norwegian Sea in autumn. Deep Sea Res 38(10):1341-1360

Davoll PJ, Silver MW (1986) Marine snow aggregates: life history sequence and microbial community of abandoned larvacean houses from Monterey Bay, California. Mar Ecol Prog Ser 33:111-120

Fenaux R (1985) Rhythm of secretion of Oikopleurid's houses. Bull Mar Sci 37(2):498-503

Fowler SW, Knauer GA (1986) Role of large particles in the transport of elements and organic compounds through the oceanic water column. Prog Oceanogr 16:147-194

Gorsky G, Fisher NS, Fowler SW (1984) Biogenic debris from the pelagic tunicate, Oikopleura dioica, and its role in the vertical flux of a transuranium element. Estuar Coast Shelf Sci 18:13-23

Hill PS (1992) Reconciling aggregation theory with observed vertical flux following phytoplankton blooms. J Geophys Res 97:2295-2308

Kiørboe T, Hansen JLS, Alldredge AL, Jackson GA, Passow U, Dam HG, Drapeau DT, Waite A, Garcia C (1996) Sedimentation of phytoplankton during a spring diatom bloom: rates and mechanisms. J Mar Res 54:in press

King KR, Hollibaugh JT, Azam F (1980) Predator prey interaction between the larvacean Oikopleura dioica and bacterioplankton in enclosed water columns. Mar Biol 56:49-57

Logan BE, Alldredge A.L (1989) Potential for increased nutrient uptake by flocculating diatoms. Mar Biol 101:443-450

Lundsgaard C (1995) Use of high viscosity medium in studies of aggregates. In: Floderus $S$ (ed) Sediment trap studies in the Nordic Countries 3. NurmiPrint OY, Nurmijärvi, p 141-152

Morris RJ, Bone Q, Head R, Braconnot JC, Nival P (1988) Role of salps in the flux of organic matter to the bottom of the Ligurian Sea. Mar Biol 97:237-241

Paffenhöfer GA (1973) The cultivation of an appendicularian through numerous generations. Mar Biol 22:183-185

Paffenhoffer GA (1975) On the biology of appendicularia of the southeastern North Sea. Proc 10th Eur Symp Mar Biol $2: 437-455$

Pomeroy LR, Deibel D (1980) Aggregation of organıc matter by pelagic tunicates. Lmmol Oceanogr 25(4):643-652

Seki H (1973) Red tide of Oikopleura in Saanich Inlet. La Mer $11\{3\}: 153-158$

Silver MW, Alldredge A.L (1981) Bathypelagic marne snow deep-sea algal and detrital community. J Plankton Res 39(3):501-530

Steinberg DK, Silver MW, Pilskaln CH, Coale SL, Paduan JB (1994) Midwater zooplankton communities on pelagic detritus (giant larvacean houses) in Monterey Bay, California. Limnol Oceanogr 39(7):1606-1620

Stoltzenbach KD (1993) Scavenging of small particles by fastsinking porous aggregates. Deep Sea Res 40(2):359-369

Taguchı S (1982) Seasonal study of fecal pellets and discarded houses of appendicularians in a subtropical inlet, Kaneohe Bay, Hawaii. Estuar Coast Shelf Res 14:545-555 